\title{
The nature of trapping centers in amorphous biphenyl containing polymer
}

\author{
A.F.Adadurov, A.I.Bedrik, E.C.Velmozhnaya, \\ P.N.Zhmurin, V.N.Lebedev, V.D.Titskaya \\ Institute for Scintillation Materials, STC "Institute for Single Crystals", \\ National Academy of Sciences of Ukraine, \\ 60 Lenin Ave., 61001 Kharkiv, Ukraine
}

Received September 7, 2010

\begin{abstract}
The study of optical properties of methyl methacrylate and 4-vinylbiphenyl copolymers in a solid amorphous solution of the polymer has made it possible to establish the non-excimer nature of energy traps in the polymer chain. These traps are related to formation of collective states including the macromolecule chromophore groups. The shortening of the trapping state decay time in the 4-vinylbiphenyl homopolymer comparing to the copolymer is observed.
\end{abstract}

\begin{abstract}
Исследование оптических свойств сополимеров метилметакрилата с винилдифенилом в твердом аморфном растворе полимера позволило установить неэксимерную природу ловушек энергии в полимерной цепи. Данные ловушки связаны с возможностью создания коллективных состояний хромофорными группами макромолекулы. Установлено укорочение времени затухания люминесценции ловушечных состояний при переходе от сополимера к гомополимеру винилдифенила.
\end{abstract}

\section{Introduction}

Much attention has been paid and still is paid to the problem of energy migration in organic macromolecules carrying chromophore groups in a side chain [1-3]. The interest in that problem is defined by the possibility to make use of the energy migration along chromophore units of a macromolecule for energy transfer to some reaction centers (the so-called antenna effect) [4]. The main problem in designing of macromolecule providing an efficient energy transfer along the chain is connected with self-organizing energy traps appearing in the macromolecule chromophore subsystem. Excimer or exciplex formations (EF) are most often regarded as such traps. They occur when two chromophore, one of which is excited, are placed in a close proximity [5-9]. Such formations are observed practically in all macromolecules containing aromatic chromophore groups. Some authors
$[3,4]$ even proposed a way to minimize the amount of such EF traps by providing the alternative systems. It is to note that transport properties of polymer molecules were mostly studied in solutions of macromolecules. But as far as EF depend on mutual arrangement of chromophore pendant groups, their properties must depend on the polymer matrix state. So in polystyrene solution, we can observe not only phenyl chromophore peak $(279 \mathrm{~nm})$ but also EF peak $(330 \mathrm{~nm})$ [14]. On the contrary, in polystyrene films, the only single EF peak at $330 \mathrm{~nm}$ is observed [9]. Therefore, to realize the antenna effect in solid polymer, it is important to know the type of traps therein. While this problem is more or less satisfactory studied for polystyrene macromolecules, it is essentially not investigated for molecules with more complex chromophore structure. The main purpose of the present work is to study the peculiarities of 
trap states in a solid solution of methyl methacrylate (MMA) and 4-vinylbiphenyl.

\section{Experimental}

The starting materials for samples preparation were commercially available 4-vinylbiphenyl and methyl methacrylate (Aldrich). The products obtained were purified by re crystallization from benzene followed by chromatography on silica gel. $T_{m}=153^{\circ} \mathrm{C}$. The steady-state spectra of absorption and emission were studied at room temperature by means of Fluoro-Max-4 (HORIBA Jobin Ivon Inc.) spectrofluorometer. The decay kinetics was measured by Combined Steady State and Lifetime Spectrometer FLS-920 (Edinburgh Instruments). The excitation source was a nanosecond flash lamp with the $1 \mathrm{~ns}$ pulse width and $40 \mathrm{kHz}$ repetition rate.

\section{Results and discussion}

The luminescence of 4-polyvinylbiphenyl chromophore moieties is most similar to luminescence of izopropylbenzene, which thus was taken as the model compound. Its optical properties can be characterized first of all by positions of absorption spectrum maximum $(279 \mathrm{~nm})$, luminescence spectrum maxima (309 and $317 \mathrm{~nm}$ ), and the excited state lifetime of $13.7 \mathrm{~ns}$ (in hexane solution) [14].

The 4-vinylbiphenyl luminescence spectrum maximum is known to be somewhat shifted to the long-wave region as compared to that of izopropylbenzene and located at 321 and $334 \mathrm{~nm}$ [11]. In measured MMA+4VBPH luminescence spectra (Fig. 1), the peak caused by the chromophore embedded in the polymer chain $(317 \mathrm{~nm})$ and double peak at 383 and $401 \mathrm{~nm}$ wavelengths are pronounced. The same peaks (but a broad one instead of double) are also observed in vinylbiphenyl solutions $[10,11]$. Those are usually explained by the EF presence in the chain. It is to note that the presence of such EF is unexpected because biphenyl molecules are weakly aggregating and the EF are essentially unobservable in biphenyl solution.

The excimers are known to have no absorption band. So if the double peak observed in the luminescence spectrum is caused by EF, then in excitation spectrum one must observe only peaks of excimer "constituents" (single chromophore moieties) at $279 \mathrm{~nm}$. But as it seen in Fig. 2, the maximum of copolymer excitation is at $388 \mathrm{~nm}$ wavelength which differs consider-

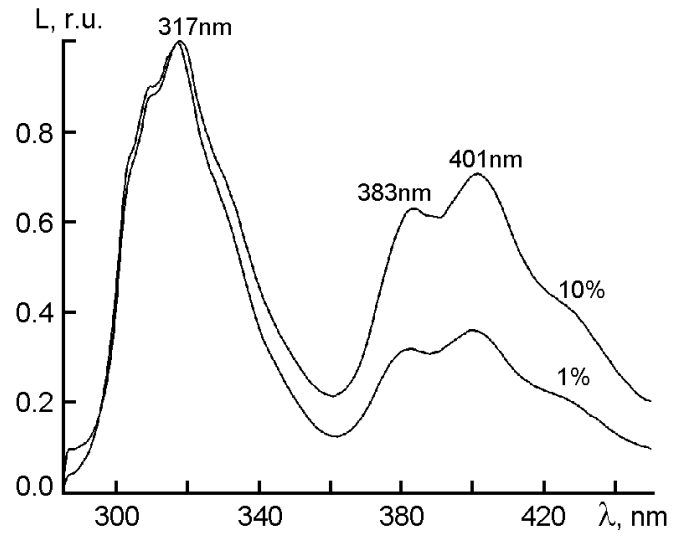

Fig. 1. Luminescence spectra of methylmetacrylate copolymer with $1 \%$ and $10 \%$ 4-vinylbiphenyl.

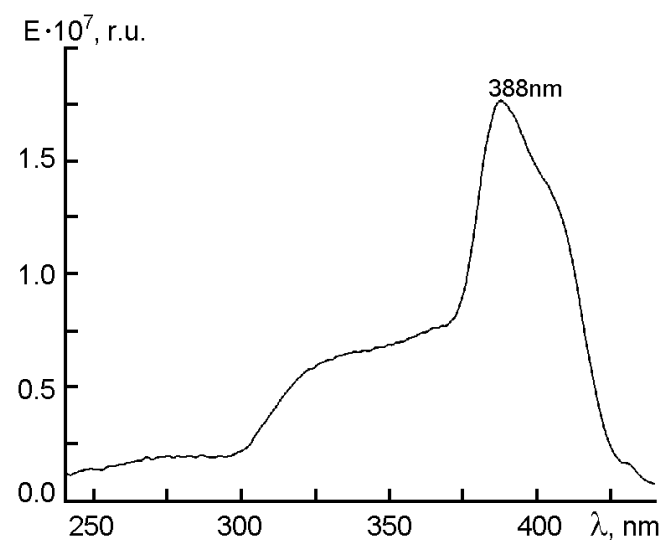

Fig. 2. Excitation spectrum of PMMA + 1 wt. \% 4 -vinylbiphenyl. Observation wavelength $450 \mathrm{~nm}$.

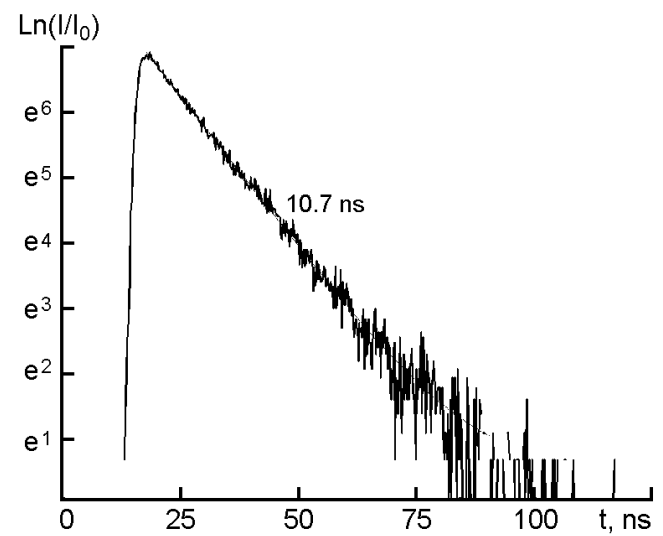

Fig. 3. Luminescence decay of methyl metacrylate and 4 -vinylbiphenyl copolymer at $320 \mathrm{~nm}$ wavelength.

ably from the expected position. Therefore, the conclusion can be made that the luminescence centers related to the long-wave spectral band cannot be the excimer forma- 


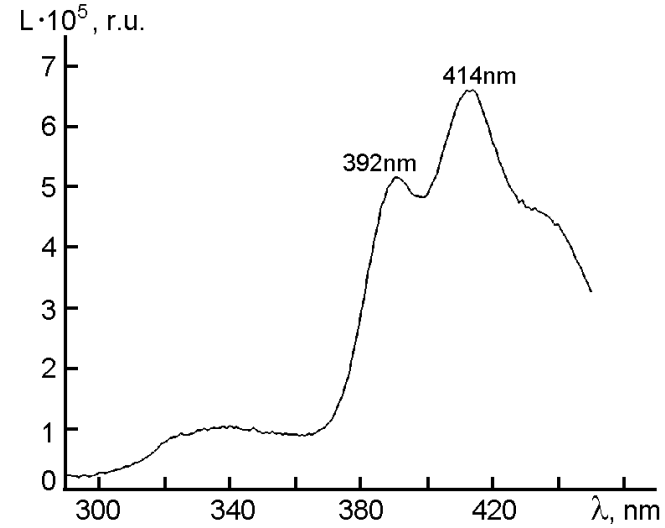

Fig. 4. Luminescence spectrum of $\mathrm{P} 4 \mathrm{VBPH}$ homopolymer film.

tions. The energy levels of that center exist also in the ground (unexcited) state.

The luminescence decay times of vinylbiphenyl measured at $320 \mathrm{~nm}$ and $400 \mathrm{~nm}$ wavelengths under excitation by a pulse $285 \mathrm{~nm}$ light source appeared to be the same and equal to $10.7 \mathrm{~ns}$ (Fig. 3). The observed coincidence of luminescence times at different wavelengths shows a close relation of long-wave luminescence centers with the copolymer chromophore groups rather than a presence of luminescent impurity molecules. Note that the decay time did not changed with vinylbiphenyl concentration up to 10 wt $\%$. When the content of vinylbiphenyl in MMA+4VBPH copolymer is increased, there is a gradual decreasing of the spectrum short-wave part. The luminescence of $\mathrm{P} 4 \mathrm{VBPH}$ homopolymer consists essentially of the long-wave part only (Fig. 4). As it seen in the Figure, in the luminescence spectra of both the P4VBPH homopolymer and the copolymer, a weak short-wave peak related to chromophore moiety luminescence can be allocated. The peak of longway luminescence is shifted towards the red region nearly by $10 \mathrm{~nm}$ as compared to the copolymer.

To eliminate the influence of luminescence of non-polymerized aggregates of vinylbiphenyl molecules, the polymer was dissolved in toluene and then reprecipitated in tetrahydrofuran. After repeated dissolution and precipitation, the obtained polymer was precipitated onto a quartz substrate. It was found that in the luminescence spectrum of the sample obtained in such a way, the peak of chromophore luminescence at $320 \mathrm{~nm}$ wavelength is totally absent (Fig. 5).

If the origin of observed luminescence is connected with mutual stacking of chromo-

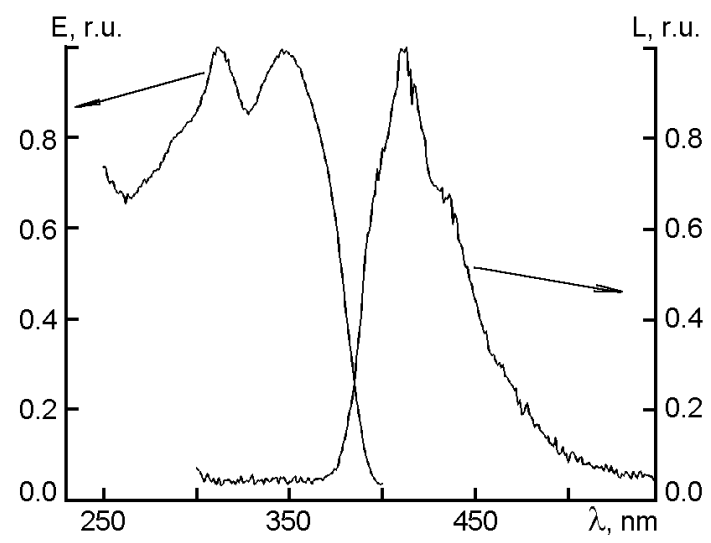

Fig. 5. Luminescence and excitation spectra of P4VBPH homopolymer film.

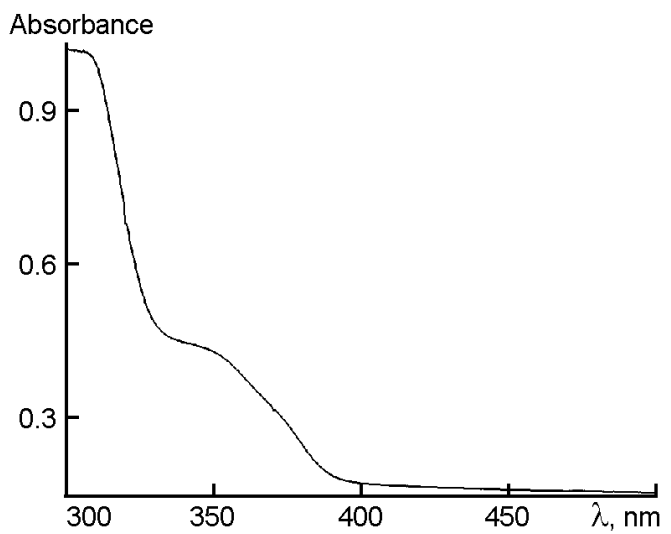

Fig. 6. Absorption spectrum of P4VBPH homopolymer film.

phore groups in polybiphenyl macromolecules, then the absence of specific peak at $320 \mathrm{~nm}$ may be caused by a higher ordering degree in precipitated polybiphenyl films. In this case, the excitation spectrum (Fig. 5) and absorption spectrum (Fig. 6) of obtained films have the specific maximum at $350 \mathrm{~nm}$. Note that the intensity of that absorption peak is much lower than that of chromophore groups.

The luminescence decay curves for P4VBPH homopolymer are presented in Fig. 7. As is seen comparing Fig. 7 and Fig. 3 , the lifetime is decreased from $10 \mathrm{~ns}$ for copolymer to $1 \mathrm{~ns}$ for homopolymer. The lifetime of precipitated sample is somewhat lesser comparing to bulk polyvinylbiphenyl sample.

The observed luminescence properties of MMA+4VBPH copolymers can be satisfactory described by the formation model of excitonlike collective states states which are usually observed in molecular crystals. These properties are most pronounced in $J$-aggregates [12]. The spatial arrangement rigidity of the 


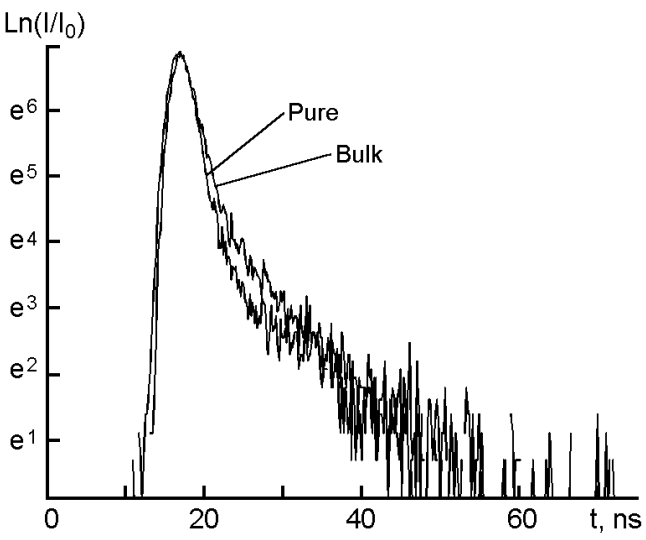

Fig. 7. Luminescence decay curves of P4VBPH homopolymer.

chromophores in $\mathrm{MMA}+4 \mathrm{VBPH}$ and $\mathrm{P} 4 \mathrm{VBPH}$ macromolecules may result in their flattening. It is to note that the angle between the phenyl planes in biphenyl molecule is $35^{\circ}$, which in turn must increase the intermolecular chromophore interaction. This interaction can cause a lowering of ground state energy which is actually observed in MMA+VBPH copolymers. But in the copolymer, there is a high probability do not have the same chromophores in a close proximity. Therefore, in the copolymer luminescence spectrum, we observe peaks of single biphenyl moieties at $317 \mathrm{~nm}$ besides the peak of bonded interchromophore group (the maximum of vinylbiphenyl luminescence is at $335 \mathrm{~nm}$ ). When concentration of chromophore groups is increased, the formation of collective states including a larger number of chromophores becomes possible. The energy of these states is lowered, which is observed in luminescence spectra. Indeed, the observed spectrum of homopolymer luminescence is shifted into the red region nearly by $10 \mathrm{~nm}$.

The second manifestation of excited states grouping is their lifetime decrease. It is known that the luminescence time of collective states must decrease in proportion to the number of coherently bound molecules. The main factor affecting this effect in polymer systems is the topological and dynamical disorder factor [13]. This factor causes a dephasing of collective states which affects their lifetimes. Therefore, it can be said that the limiting lifetimes of collective formations are changed between $\tau_{0} / N_{c}$ in $\mathrm{MMA}+4 \mathrm{VBPH}$ and $\tau_{0}$ in $\mathrm{P} 4 \mathrm{VBPH}$ homopolymer.

\section{Conclusion}

The study of optical properties of MMA+4VBPH copolymer solid solutions and P4VBPH homopolymer has allowed us to establish the influence of the macromolecule phase composition on the luminescence properties. The observed collective states in polyvinylbiphenyl which include several chromophore moeities of the macromolecule can effectively collect the excitation energy of chromophore groups and reemit it in $410 \mathrm{~nm}$ region which is traditionally used for optical radiation registration by PMT. The possible ordering of macromolecule chromophore groups can significantly decrease the lifetime of excited states without significant loss of energy. The search for systems with ordered chromophore moieties in a macromolecule is the way to obtain the fast luminescence systems required to detect the high-energy particles.

\section{References}

1. D.A.Holden, J.E.Guillet, Macromolecules, 13, 289 (1980).

2. G.Liu, J.Phys. Chem., 99, 5465 (1995).

3. Y.Itoh, Europ. Polymer J., 36, 2605 (2000).

4. S.Weber, Chem.Rev., 90, 1469 (1990).

5. J.Sung, J.Lee, S.Lee, J.Chem.Phys., 118, 414 (2003).

6. H.Saigusa, E.C.Lim, Chem. Phys. Lett., 336, 65 (2001).

7. J.C.Amicangelo, J.Phys. Chem. A, 109, 9174 (2005).

8. Pascal de Saint Claire, J.Phys.Chem.B, 110, 7334 (2006).

9. G.Zhang, J.K.Tomas, J. Phys. Chem., 99, 11203 (1995).

10. E.Abuin, E.Lissi, L.Gargallo, D.Radic, Europ. Polymer J., 18, 319 (1982).

11. F.Bai, C.H.Chang, S.E.Weber, Macromolecules, 19, 2798 (1986).

12. V.V.Egorov, M.V.Alfimov, Phys.Usp., 50, 985 (2007).

13. R.D.Jenkins, D.L.Andrews, Photochem.Photobiol. Sci., 2, 130 (2003).

14. I.B.Berlman, Handbook of Fluorescence Spectra of Aromatic Molecules, Acad. Press, New York \& London (1965). 


\title{
Природа центрів захоплення енергії в аморфному біфенілвмісному полімері
}

\author{
О.Ф.Ададуров, О.І.Бедрик, О.С.Вельможна, \\ П.М.Жмурін, В.М.Лебедєв, В.Д.Тицькая
}

\begin{abstract}
Дослідження оптичних властивостей співполімерів метилметакрилату з вінілбіфенілом у твердому аморфному розчині полімеру дозволило встановити неексимерну природу пасток енергії у полімерному ланцюгу. Ці пастки пов'язані з можливістю створення колективних станів хромофорними групами макромолекули. Встановлено скорочення часу затухання люмінесценції при переході від співполімеру до гомополімеру вінілбіфенілу.
\end{abstract}

